\title{
PEMBERDAYAAN GURU MATEMATIKA SMP DALAM MENGEMBANGKAN NUMERASI SISWA KONTEKS PANDEMI COVID-19
}

\author{
Tatag Yuli Eko Siswono1, Mega Teguh Budiarto', \\ Yusuf Fuad ${ }^{1}$, Siti Khabibah ${ }^{1}$ \\ 1Pascasarjana, Universitas Negeri Surabaya, Surabaya, Indonesia 60213 \\ email korespondensi: tatagsiswono@unesa.ac.id
}

Diterima: (24-11-2021), Revisi: (23-12-2021), Diterbitkan: (31-12-2021)

\begin{abstract}
ABSTRAK
Tujuan penelitian ini adalah mendeskripsikan kegiatan pemberdayaan guru matematika SMP dalam mengembangkan tugas numerasi siswa menggunakan konteks pandemi Covid-19 untuk pembelajaran matematika menggunakan google classroom. Penelitian deskriptif ini melibatkan 18 guru matematika SMP di kabupaten Nganjuk sebagai sasaran. Instrumen penelitian berupa tugas pembuatan soal, tugas mengembangan desain pembelajaran dalam google classroom, angket pemahaman guru tentang numerasi dan angket respon guru setelah pemberdayaan guru. Analisis data dilakukan secara deskriptif kuantitatif dan kualitatif dari semua data. Hasil penelitian menunjukkan kegiatan pemberdayaan guru dapat meningkatkan pemahaman guru dalam numerasi, keterampilan dalam membuat tugas numerasi dan melakukan penilaian.
\end{abstract}

Kata kunci: numerasi, konteks, pandemi covid-19. 


\begin{abstract}
The study's aim is to describe an empowerment activities of junior high school mathematics teachers in developing students' numeracy tasks using the context of the Covid-19 pandemic for teaching and learning mathematics using google classroom. This descriptive study involved 18 junior high school mathematics teachers in Nganjuk district as targets. Some research instruments are the numeracy task design, the task of developing learning designs in the google classroom, a questionnaire of teacher's understanding of numeracy and the teacher's response questionnaire after the teacher empowerment training. Data analysis was carried out by quantitative and qualitative descriptive of all data. The results pointed out that empowerment activities through teacher training can improve teachers' understanding of numeracy and skills in making numeracy tasks and conducting assessments.
\end{abstract}

Key words: numeracy, context, pandemic covid-19

\title{
Pendahuluan
}

COVID-19 merupakan penyakit menular yang disebabkan oleh sindrom pernafasan akut coronavirus 2 (Hui, et al., 2020). Keadaan di luar prediksi wabah ini telah membawa perubahan yang mendesak pada berbagai sektor di berbagai negara. Indonesia merupakan salah satu negara yang masuk dalam kondisi gawat darurat akibat dampak pandemi ini. Tercatat pada 4 April 2021 sebanyak 6.731 orang tercatat terjangkit virus corona (Covid-19), sehingga total kasus positif di Indonesia sampai hari itu mencapai 1.534.255 kasus. Dari total kasus positif itu 1.375.877 pasien dinyatakan sembuh atau ada peningkatan 9.663 kasus sembuh dan kasus meninggal dunia mencapai 41.669 jiwa, termasuk tambahan korban meninggal hari itu sebanyak 427 orang ( (CNN Indonesia, 2021). Peningkatan kasus Covid-19 ini memerlukan peran serta masyarakat terutama pendidik matematika dalam upaya mencegah dan mengatasi semakin mewabahnya pandemi Covid-19. Guru matematika perlu diberdayakan dalam menanggulangi masalah tersebut.

Pada masa pandemi, guru memiliki dan dituntut melaksanakan banyak peran tambahan, yaitu: (1) memastikan tercapainya tujuan pendidikan dan pemenuhan target akademik dan non akademik, mempersiapkan materi dan hasil evaluasi pembelajaran; (2) guru juga memiliki tanggung jawab dalam memastikan keselamatan guru didik secara fisik dan psikis; (3) memberikan penguatan aktif dan memberikan pemahaman kepada siswa guna mentaati semua protokol kesehatan; (4). Dengan tetap memprioritaskan fasilitasi terhadap pembelajaran siswa, guru kini harus senantiasa memberikan dukungan emosional bagi siswa, orang tua, dan 
juga keluarga; (5) guru harus dapat melakukan komunikasi dan mengembangkan kerja sama yang baik dengan kepala sekolah, orang tua/keluarga siswa untuk membangun kepercayaan dan mendukung proses pendidikan (Adit, 2020).

Selanjutnya dijelaskan pula oleh Adit (2020) bahwa guru perlu memiliki kompetensi sebagai berikut.

1. Kemampuan berinovasi, memanfaatkan bermacam digital tools, menyelenggarakan kelas online, penerapan kurikulum yang memperkuat model multidisiplin dan kolaboratif dalam belajar mengajar.

2. Kemampuan menata ulang akuntabilitas, menentukan metode dalam proses assesmen.

3. Kemampuan menyelenggarakan pendidikan yang membantu siswa berkembang secara akademis, fisik dan psikis, dengan menyeimbangkan antara "old" knowledge dengan mekanisme digital.

4. Kemampuan menyajikan pendidikan dan pengajaran yang merata termasuk bagi yang paling rentan.

5. Kemampuan komunikasi untuk mensinergikan pandangan dan visi proses pendidikan anak dengan kepala sekolah termasuk orang tua/ keluarga.

Untuk mengatasi masalah tersebut, guru perlu dibekali pengetahuan dan kemampuan untuk mentaati protokol kesehatan dan memfasilitasi pembelajaran yang sesuai dengan tuntutan kurikulum yaitu numerasi, serta memberikan keterampilan pengajaran di masa pandemi.

Numerasi merupakan kemampuan untuk menangani bilangan dan data untuk mengevaluasi pernyataan atau informasi berdasarkan masalah yang meliputi proses estimasi dan mental pada konteks dunia nyata (Dewayani, et al., 2021). Numerasi merupakan cerminan dari perubahan dalam kehidupan modern yang berperan penting karena membantu orang untuk hidup layak sekarang dan terus berlanjut berpartisipasi dalam masyarakat (Craig, 2018). Hasil penelitian menunjukkan numerasi 34 siswa kelas IV di salah satu sekolah di Kota Bandung dalam menyelesaikan masalah tidak terstuktur kurang memuaskan karena siswa kesulitan membangun strategi penyelesaian dan salah membuat kesimpulan (Mahmud \& Pratiwi, 2019). Penelitian yang dilakukan kepada 60 guru menunjukkan bahwa siswa berkemampuan tinggi mampu menyelesaikan masalah, namun siswa berkemampuan sedang dan rendah belum menunjukkan prestasi yang baik. Studi kasus yang dilakukan Callingham, dkk menyatakan bahwa guru-guru di daerah ter- 
pencil di Tasmania tidak mengenali kompleksitas numerasi, namun mereka berpendapat bahwa numerasi mempunyai peranan penting dalam kehidupan (Callingham, Beswick, \& Ferme, 2015).

Numerasi tidak hanya berhubungan dengan penerapan konsep bilangan, namun mencakup gagasan untuk dapat melakukan komunikasi efektif dengan orang lain melalui konsep dasar matematika (Westwood, 2000). Numerasi bukan sekadar pemahaman konsep dan kompetensi yang berhubungan dengan angka dan pengukuran, namun juga keterampilan dan sikap kepercayaan diri dalam penanganan dan interpretasi data kuantitatif (Taskin \& Tugrul, 2014). Untuk itu diperlukan suatu upaya agar numerasi dapat lebih dimaksimalkan. Salah satunya dalam bentuk pemberdayaan guru matematika.

Selain dimaknai sebagai memberikan kekuasaan, mengalihkan kekuatan atau mendelegasikan otoritas kepada pihak yang kurang atau belum berdaya, pemberdayaan juga dimaknai memberikan kemampuan atau keberdayaan serta melakukan sesuatu (Prijono \& Pranarka, 1996). Pemberdayaan merupakan suatu usaha untuk memberikan daya atau meningkatkan daya, yang intinya memuat tiga hal yaitu pengembangan (enabling), potensi atau daya (empowering), memperkuat terciptanya kemandirian (Winarni, 1998). Pemberdayaan memiliki makna membangkitkan sumber daya, kesempatan, pengetahuan dan keterampilan masyarakat untuk meningkatkan kapasitas dalam menentukan masa depan mereka (Suparjan \& Suyatna, 2003).

Pemberdayaan adalah proses perubahan yang bersifat multidimensi yang bertujuan untuk mewujudkan kondisi seimbang antara kebutuhan dan sumber daya yang dilakukan dengan cara mengantisipasi, menyelesaikan persoalan, dan memanfaatkan peluang serta sumber daya yang ada (Soetomo, 2009). Pemberdayaan adalah upaya untuk membangun daya itu, dengan mendorong, memotivasikan, dan membangkitkan kesadaran akan potensi yang dimilikinya serta berupaya untuk mengembangkannya (Hadi, 2010). Pemberdayaan dalam penelitian ini diartikan sebagai upaya melalui suatu pelatihan atau pembinaan dengan mengembangkan potensi guru untuk mendorong dan memberikan bekal kompetensi guru dalam numerasi.

Pola pemberdayaan ditata dan dikelola secara intensif untuk menjamin peningkatan kompetensi guru secara berkesinambungan, sehingga akan memberikan dampak positif terhadap kualitas pembelajaran dan siswa akan senang belajar da- 
lam berbagai situasi khususnya dalam pandemi COVID-19. Adapun gambaran umum situasi yang dihadapi adalah (1) perlu peningkatan peran dan kesadaran guru dalam mengatasi pandemi Covid-19 serta pemahaman guru matematika SMP tentang numerasi, (2) terbatasnya program pemberdayaan yang berfokus pada perancangan tugas numerasi dengan konteks pandemi Covid-19.

Konteks merupakan situasi yang menjadi suatu latar atau setting sesuatu, misalkan pada soal atau masalah konteks dapat terkait dengan kehidupan sehari-hari atau aspek bidang studi lain. Konteks membatasi suatu lingkup masalah. Kadangkala untuk suatu konteks, soal atau masalah dapat berbeda cara pandang dan penyelesaiannya. Dalam PISA, konteks dan konten menjadi perhatian dalam membuat tugas. Konten pada PISA yang dapat dikaitkan dengan Covid-19 diuraikan sebagai berikut.

1. Bilangan (misalnya terinfeksi, mortalitas, ODP, sembuh)

2. Shape \& Space (misalnya bentuk Virus, Zona Merah)

3. Change \& Relationship (misalnya fungsi eksponensial, linear, pemodelan)

4. Uncertainty \& Data (misalnya ketidakpastian, berita, data dan informasi terdisplay, di ragam media)

Covid-19 dalam PISA merupakan konteks societal (konteks umum) dan scientific (konteks ilmiah). Konteks lain dapat saja dikaitkan, yaitu konteks personal/ pribadi dan konteks pekerjaan/ occupational (Siswono, et al., 2019).

Tujuan penelitian ini adalah mendeskripsikan hasil kegiatan pemberdayaan guru matematika SMP dalam mengembangkan tugas numerasi menggunakan konteks pandemi Covid-19 untuk pembelajaran matematika menggunakan google classroom.

\section{Metode Penelitian}

Penelitian ini melibatkan 18 guru matematika SMP Negeri di kabupaten Nganjuk sebagai sasaran. Instrumen penelitian berupa angket pra-kegiatan, tugas pembuatan soal, tugas pengembangan desain pembelajaran dalam google classroom, angket pemahaman guru tentang numerasi dan angket respon guru setelah pelatihan pemberdayaan guru. Instrumen pra-kegiatan memuat tiga pertanyaan tentang keikutsertaan pemberdayaan, workshop, atau kegiatan lain tentang numerasi, pengertian numerasi, dan soal yang termasuk tugas numerasi. Instrumen ini diisi 
secara online menggunakan aplikasi google form. Setelah kegiatan diberikan angket dan isian pada google form tentang tugas pembuatan soal, tugas mengembangan desain pembelajaran dalam google classroom, angket pemahaman guru tentang numerasi. Tugas terdiri dari 4 butir, yaitu pertanyaan tentang pengertian numerasi, tugas membuat soal dan rubrik penilaiannya, dan bukti tugas numerasi pada google classroom. Angket respon guru setelah penelitian terdiri dari 8 butir pendapat dengan pilihan "Sangat Setuju (SS), Setuju (S), Kurang Setuju (KS), dan Tidak Setuju (TS)" dan isian singkat pendapat/komentar dalam kegiatan. Angket tersebut menggunakan google form. Langkah pengumpulan data ditunjukkan pada diagram berikut.

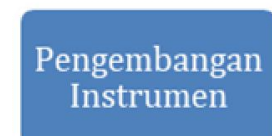

Penyimpulan

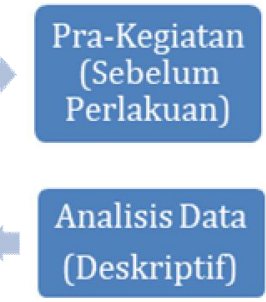

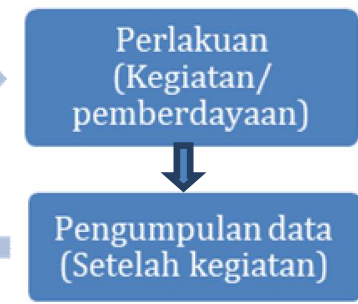

Perlakuan

(Kegiatan/

pemberdayaan)

Pengumpulan data

(Setelah kegiatan]

Gambar 1. Langkah Pengumpulan Data

Perlakuan atau kegiatan pemberdayaan meliputi penjelasan tentang peran guru di masa pandemi, konsep numerasi, penilaian numerasi, dan pembelajaran numerasi menggunakan google classroom yang dilakukan dengan tatap muka (offline). Kegiatan selanjutnya workshop pembuatan tugas numerasi dan merancang pembelajaran numerasi menggunakan google classroom secara online. Berikutnya tugas mandiri memanfaatkan google classroom dengan mengimplementasi di kelas.

Analisis data dilakukan secara deskriptif kuantitatif dan kualitatif. Data kuantitatif dari hasil angket pra-kegiatan, angket pemahaman guru tentang numerasi dan angket respon guru setelah pelatihan pemberdayaan guru dihitung, ditabulasikan, dan dipersentasekan. Data kualitatif berupa hasil jawaban tugas dan pendapat tugas pembuatan soal, tugas pengembangan desain pembelajaran dalam google classroom dianalisis dengan melihat kesamaan antar jawaban, diperiksa keakuratannya, dan ditata kemudian disimpulkan. Indikator pemberdayaan guru matematika SMP dalam mengembangkan numerasi guru adalah peningkatan pemahaman guru tentang konsep numerasi sebelum kegiatan (pra-kegiatan) dibandingkan setelah kegiatan, kemampuan membedakan tugas yang termasuk tugas numerasi dan non-numerasi, dan kemampuan merancang tugas tersebut, serta 
persepsi positif guru setelah kegiatan pemberdayaan.

\section{Hasil dan Pembahasan}

Hasil penelitian menunjukkan 75\% guru belum pernah mendapatkan pelatihan, workshop, atau kegiatan semacam ini. Pemahaman guru tentang numerasi belum lengkap, masih umum karena para guru mengatakan numerasi sebagai "penerapan operasi hitung, cara berpikir kreatif, kemampuan matematika dalam aspek keterampilan, penerapan pembelajaran yang berhubungan angka, atau keterampilan/ kemampuan memecahkan masalah dengan menggunakan konsep matematika". Hal tersebut berbeda dengan konsep numerasi bahwa numerasi tidak sekedar operasi (Atmazaki, et al., 2017, Westwood, 2000) dan bukan cara berpikir kreatif atau suatu strategi pembelajaran (Dewayani, et al., 2021).

Ketika diberikan tiga soal cerita dengan karakteristik : soal A merupakan soal matematika yang terkait dengan kehidupan sehari-hari tetapi konteksnya terpisah (border problem), soal B merupakan soal matematika yang setipe dengan soal A tetapi lebih nyata dalam kehidupan sehari-hari, dan soal C merupakan soal cerita termasuk tipe terbungkus (wrapped problem) dan konteksnya ada dalam kehidupan sehari-hari (Siswono, et al., 2019). Soal yang termasuk soal numerasi adalah soal C yang dipilih 25\% guru, dan soal yang bukan merupakan tugas numerasi adalah soal A dan B yang dipilih 75\% guru.

Hasil setelah pemberdayaan guru sudah memahami numerasi sebagai suatu kemampuan untuk mengakses, menggunakan, menafsirkan, dan mengomunikasikan informasi dan ide matematika, untuk terlibat dalam dan mengelola tuntutan matematika dari berbagai situasi dalam kehidupan sehari-hari (Westwood, 2000). Dikatakan juga numerasi adalah kemampuan untuk mengaplikasikan konsep bilangan dan keterampilan operasi hitung di dalam kehidupan sehari-hari (Atmazaki, et al., 2017, Han, et al., 2017).

Guru juga telah mampu membuat soal numerasi seperti "Sabda ingin membagikan paket kesehatan. Paket itu berisi hand sanitizer dan masker. Ia membeli sejumlah hand sanitizer dan masker. Ada 12 hand sanitizer dan 24 masker. Setiap paket akan berisi hand sanitizer dan masker dengan jumlah yang sama, Sabda ingin membuat sebanyak mungkin paket. Jika ada sisa, maka akan ia gunakan sendiri. Berapa hand sanitizer dan masker yang Sabda gunakan sendiri? Jelaskan!”. Contoh 
soal lain yang dibuat guru dapat dilihat pada Gambar 2 berikut.

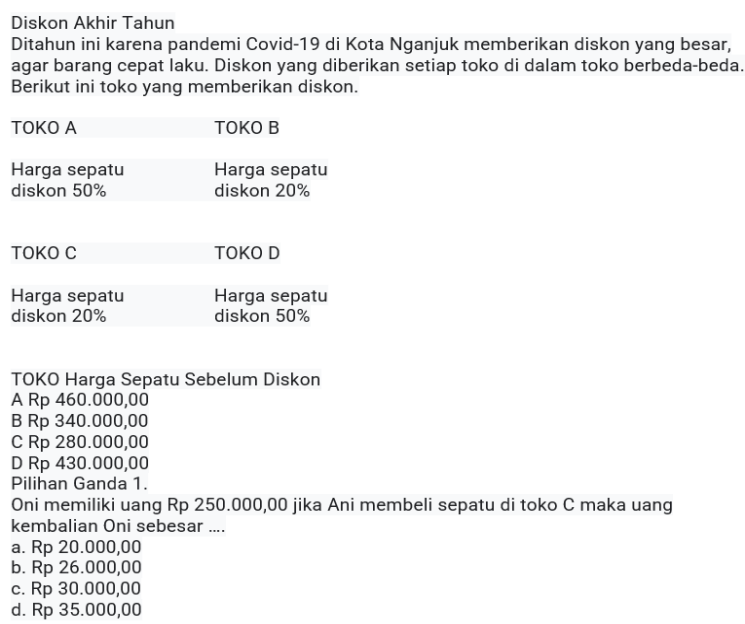

Gambar 2. Contoh soal yang dibuat guru

Persepsi guru dan hasil pemberdayaan lebih dari 94,1\% guru memberikan apresiasi positif terhadap kegiatan dan mengharapkan kegiatan ditindaklanjuti.

Tabel 1. Persepsi Guru dalam Kegiatan Pemberdayaan Numerasi

\begin{tabular}{llc}
\hline No & \multicolumn{1}{c}{ Nama } & Positif (\%) \\
\hline 1. & $\begin{array}{l}\text { Guru memahami tentang numerasi, penilaian, dan pembelajaran } \\
\text { memanfaatkan teknologi }\end{array}$ & 100 \\
2. $\quad \begin{array}{l}\text { Materi pemberdayaan ini memberikan pengetahuan dan pengala- } \\
\text { man tentang numerasi dan pembelajaran di kelas yang bermanfaat }\end{array}$ & 94,1 \\
3. $\quad \begin{array}{l}\text { Pemberdayaan ini memberikan pengetahuan dan pengalaman ten- } \\
\text { tang cara penilaian numerasi untuk siswa di kelas }\end{array}$ & 94,1 \\
4. $\quad \begin{array}{l}\text { Pemberdayaan ini menginspirasi guru untuk melaksanakan pembe- } \\
\text { lajaran matematika menggunakan teknologi seperti Google Class- }\end{array}$ & 94,1 \\
$\quad \begin{array}{l}\text { room terutama pada pengembangan numerasi siswa. } \\
\text { Pemberdayaan ini menumbuhkan keyakinan pada guru bahwa nu- } \\
\text { merasi dengan konteks Covid-19 dapat dilaksanakan dengan efektif. }\end{array}$ & 94,1 \\
Pemberdayaan ini menumbuhkan keyakinan pada guru dapat ber- \\
$\quad \begin{array}{l}\text { peran dan terlibat dalam mengatasi pandemi Covid-19 melalui } \\
\text { pembelajaran numerasi. }\end{array}$
\end{tabular}

Hasil angket tersebut menunjukkan bahwa pemberdayaan berhasil memberikan 
dorongan, motivasi, dan membangkitkan kesadaran kepada guru untuk mengembangkan keterampilan dalam numerasi (Soetomo, 2009; Hadi, 2010). Pemberdayaan dapat mendorong untuk belajar meningkatkan kapasitas dan melakukan pengetahuan atau keterampilannya (Prijono \& Pranarka, 1996; Suparjan \& Suyatna, 2003).

\section{Kesimpulan}

Hasil penelitian menunjukkan bahwa kegiatan pemberdayaan guru matematika SMP di Nganjuk telah berhasil meningkatkan pengetahuan, kemampuan, dan keterampilan guru dalam mengembangkan tugas numerasi menggunakan konteks pandemi Covid-19 untuk pembelajaran matematika menggunakan google classroom. Kondisi awal guru yang hanya 25\% memahami konsep numerasi menjadi 100\% dapat mengenal dan mempraktek pengetahuannya di kelas. Guru juga memberikan apresiasi dan memberikan bukti bahwa pemberdayaan paling sedikit $94,1 \%$ bermanfaat dan bernilai positif sehingga perlu untuk ditindaklanjuti. Guru memahami numerasi sebagai suatu kemampuan untuk mengakses, menggunakan, menafsirkan, dan mengomunikasikan informasi dan ide matematika, untuk terlibat dalam dan mengelola tuntutan matematika dari berbagai situasi dalam kehidupan sehari-hari atau secara sederhana merupakan kemampuan untuk mengaplikasikan konsep bilangan dan keterampilan operasi hitung di dalam kehidupan sehari-hari. Berdasar hasil penelitian disarankan bahwa pemberdayaan guru dalam hal numerasi perlu ditindaklanjuti dalam rangka mendukung program pemerintah untuk mewujudkan profil pelajar Pancasila dan menggunakan bentuk kegiatan yang bervariatif dan efektif.

\section{Ucapan Terimakasih}

Terima kasih disampaikan kepada Rektor Universitas Negeri Surabaya dan Direktur Pascasarjana Unesa yang telah memberikan Hibah Kebijakan PKM Pascasarjana Nomer 829/ UN38/ HK/ PM/ 2021.

\section{Daftar Pustaka}

Adit, A. (2020). Ini Peran dan Tuntutan Kompetensi Guru di Masa Pandemi. https:/ / www.kompas.com/ edu/ read/ 2020/ 10/ 08/ 113530671/ ini-peran-da 
n-tuntutan-kompetensi-guru-di-masa-pandemi?page $=$ all.

Callingham, R., Beswick, K., \& Ferme, E. (2015). An initial exploration of teachers' numeracy in the context of professional capital. ZDM - International Journal of Math. Education, vol. 47, no. 4, pp. 549-560.

CNNIndonesia. (2021). Positif Covid Bertambah 6.731, Kematian Melonjak 427 Jiwa.

https:/ / www.cnnindonesia.com/ nasional/ 20210404143509-20-625783/ posi tif-covid-bertambah-6731-kematian-melonjak-427-jiwa.

Craig, J. (2018). The promises of numeracy. Education Studies of Mathematics, 99(1), 57-71.

Dewayani, S., Retnaningdyah, P., Susanto, D., Ikhwanudin, T., Fianto, F., Muldian, W., ... Antoro, B. (2021). Panduan Penguatan Literasi dan Numerasi di Sekolah. Jakarta: Direktorat Jenderal Pendidikan Anak Usia Dini, Pendidikan Dasar, dan Pendidikan Menengah, Kementerian Pendidikan dan Kebudayaan.

Hadi, A. P. (2010). Konsep pemberdayaan, partisipasi dan kelembagaan dalam pem-bangunan. Yayasan Agribisnis/ Pusat Pengembangan Masyarakat Agrikarya

(PPMA).http:// suniscome.50webs.com/32\%20Konsep\%20Pemberdayaan\%2 0Partisipasi\%20Kelembagaan.pdf.

Hui, D. S., Azhar, E. I., Madani, T. A., Ntoumi, F., \& Kock, R. D. (2020). The continuing 2019-nCoV epidemic threat of novel coronaviruses to global health-The latest 2019 novel coronavirus outbreak in Wuhan, China. International Journal of Infectious Diseases, 91, 264-266.

Mahmud, M. R., \& Pratiwi, I. M. (2019). Literasi Numerasi Siswa Dalam Pemecahan Masalah Tidak Terstruktur. "KALAMATIKA" Jurnal Pendidikan Matematika, Vol. 4, No. 1, pp. 69-88, 2019.

Prijono, O. S., \& Pranarka, A. M. (1996). Pemberdayaan: Konsep, kebijakan, dan implementasi. Jakarta: Centre for Strategic and International Studies.

Siswono, T., Wijayanti, P., Rosyidi, A., Kohar, A. W., \& Hartono, S. (2019). Model profesionalisme Guru: Berpikir Kreatif dan Literasi Matematika. Lamongan: Pagan Press.

Soetomo, P. (2009). Merangkai Sebuah Kerangka. Yogyakarta: Pustaka Pelajar.

Suparjan, \& Suyatna, H. (2003). Pengembangan Masyarakat dari Pembangunan Sampai Pemberdayaan. Yogyakarta: Aditya Media. 
Taskin, N., \& Tugrul, B. (2014). Investigating preschool teacher candidates ' mathematics literacy self-sufficiency beliefs on various variables. Procedia - Soc. Behav. Sci., vol. 116, pp. 3067-3071.

Westwood, P. (2000). More on children's learning. Numeracy and Learning Difficulties: Approaches to Teaching and Assessment, 17-29.

Winarni, T. (1998). Memahami Pemberdayaan Masyarakat Desa Partisipatif dalam Orientasi Pembangunan Masyarakat Desa Menyongsong Abad 21: Menuju Pemberdayaan Pelayanan Masyarakat. Yogyakarta: Aditya Media. 